\title{
EDITORIAL
}

\section{EPISTEMOLOGIA DA PESQUISA CONTÁBIL}

É inquestionável o crescimento da produção científica sobre Contabilidade e Controladoria nos últimos 8 anos. Multiplicaram-se os Programas de Pós-Graduação Stricto Sensu: atualmente são 19 Cursos de Mestrado e 3 de Doutorado. Elevaram-se, significativamente, as ofertas de Cursos de Especialização - modalidade MBA - dirigidos aos contabilistas. Foram criados Seminários, Encontros e Congressos: espaços privilegiados para apresentação e discussão de textos científicos sobre Contabilidade e Controladoria. Os Congressos da ANPCONT, iniciados em 2007, ilustram e reforçam a expansão e 0 crescimento da produção contábil. Também aumentou, extraordinariamente, a quantidade de periódicos com linha editorial dedicada, exclusivamente, às Ciências Contábeis. Considerando os principais periódicos nacionais da área de Administração e as revistas nacionais orientadas para o campo Contábil, têm-se mais de 40 títulos em circulação. A publicação de textos científicos: teses, dissertações, monografias, artigos, trabalhos dirigidos a Encontros Científicos e periódicos cresceram nos últimos anos, evidenciando-se a necessidade da condução de estudos avaliativos e de vigilância sobre a qualidade dessa produção: campo da epistemologia. Como explica Japiassu (1980), a moderna epistemologia tem como propósito o exame das condições reais de produção dos conhecimentos científicos, sem impor dogmas aos pesquisadores. Busca estudar a gênese e a estrutura dos conhecimentos científicos, tanto do ponto de vista lógico quanto dos pontos de vista lingüístico, sociológico, ideológico etc. Trata-se de uma proposta de discussão que surge ante a necessidade de se compreender e explicar como se dá a produção científica, bem como analisar aspectos do polêmico processo de avaliação de trabalhos científicos de quaisquer áreas do conhecimento, neste caso, do campo da Controladoria e Contabilidade. A amplitude e a diversidade dos assuntos, dos temas e dos problemas investigados, as diferentes alternativas para construção das plataformas teóricas que sustentam os desenvolvimentos das pesquisas, as distintas abordagens metodológicas empreendidas, as variadas estratégias de pesquisa, a diversidade de técnicas e de instrumentos de coleta de informações, dados e evidências, os diferentes planos para tratamento e análises dos resultados de uma pesquisa impõem ao leitor, avaliador e pesquisador, enfim, à comunidade contábil, extrema atenção, coerência, senso de justiça e ética. Os desafios colocados exigem compromissos e responsabilidades dos produtores e consumidores desse nobre produto. A discussão aqui empreendida é uma atitude deliberada e sistemática de busca de explicações sobre possíveis critérios para análise e avaliação dos textos científicos da área de Contabilidade e Controladoria. É amplo e complexo o debate sobre as condições que determinam as opções dos avaliadores e consumidores dos temas submetidos a um Congresso ou à editoria de um periódico. Estudos auto-avaliativos sobre a produção científica oferecem elementos para uma reflexão crítica sobre a qualidade do que se está produzindo. A função essencial da epistemologia consiste em submeter a prática dos cientistas a uma reflexão que toma por objeto as ciências em vias de se fazerem, em seu processo de gênese, de formação e de estruturação progressiva. É preciso chamar a atenção, levar a debate e apresentar sugestões para superação de possíveis insuficiências e vieses dessa produção. Impõe-se a busca do estabelecimento de padrões científicos que possam garantir e legitimar a qualidade da produção desse promissor campo de conhecimento das Ciências Sociais Aplicadas. Os padrões científicos serão definidos por nós e pelos nossos pares. O debate e o contraditório constituem essências do processo de construção de padrões e da própria ciência. Não existe uma verdade científica, existem verdades provisórias que se sucedem. Estudos sobre a produção científica - investigações epistemológicas - devem ser estimulados como forma de se apresentar, descrever e discutir a qualidade das pesquisas sobre Ciências Contábeis. Acredita-se que este esforço - passível de questionamentos, reformulações e aprimoramentos - possa chamar a atenção, levantando debates e apresentando sugestões para a superação de insuficiências e vieses identificados na produção contábil brasileira.

Prof. Dr. Gilberto de Andrade Martins 